\title{
An initial study on managing sustainability schools in
} Taiwan

\author{
Wang, Wen Sheng $₫$ \\ Department of Business Administration, National Central University, Taiwan (vincenwan@hotmail.com)
}

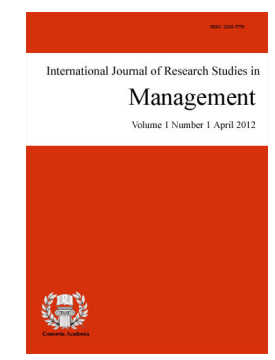

ISSN: $2243-7770$ Online ISSN: 2243-7789

OPEN ACCESS

\section{Abstract}

Issues of environmental protection and greening our Earth have been increasingly talked about in all sectors of society. European industry standards such as WEEE (Waste Electrical and Electronic Equipment) and RoHS (Restriction of Hazardous Substances) have provided policies that forces organizations to become green. In the United States, sustainability policies are also being used to evaluate the institutions' commitment towards environmental protection. In Taiwan, sustainability and green policies is not only limited to the industries, but also institutions of learning. In light of these issues, the current study shall focus on how sustainable are Taiwan higher education institutions. Using the Sustainability Tracking, Assessment and Rating System (STAR) framework of the Association for the Advancement of Sustainability in Higher Education (AASHE) of the US as a starting point, a survey questionnaire shall be administered to all higher education institutions all over Taiwan. Result shows that higher education institutions in Taiwan are engaging in sustainability strategies in all levels and functions of the organizations. Furthermore, the results are expected to fill the gap of extant literature with the in-depth investigation of the potential impact of the higher educational school on green practice and environmental performance in Taiwan.

Keywords: green school; sustainability schools; Taiwan; STARS; AASHE 


\section{An initial study on managing sustainability schools in Taiwan}

\section{Introduction}

The global advancement of technologies had caused impacts between environmental degradation and negative environment around the world (Dietz \& Rosa, 1994). Such issues have challenged most industries in Europe, United States, and other developed countries (Portney \& Ber, 2011). Thus, European countries have formulated regulations on environmental protection, such as the Waste Electrical and Electronic Equipment Regulations (WEEE) and Restrictions of Hazardous Substances (RoHS), these regulations tend to rigidly control the use of hazardous materials and encourage setting up reuse, recycling, and recovery targets for waste elimination (Zhang, 2011). Furthermore, Pujari (2006) mentioned that the issues of resource efficiency, waste and emission elimination, and environmental impact reduction have all contributed to betterment of the environment.

In the US, researchers and organizations are quite concerned with the overall impact of society to our environment. Information and strategies regarding environmental protection are gathered to evaluate the organization in terms of its sustainability. Periodic measurements regarding implementation and evaluation of industries, organizations, and schools in environmental protections are undertaken. In Taiwan, industries have been undergoing intensive competition and stringent environmental protection strategies. Likewise, in higher education institutions; the Ministry of Education (MOE) have since 2008 started a strong campaign towards a green campus environment (Kuo, 2009). Hence, the current study shall focus on how sustainable are Taiwan higher education institutions. Using the Sustainability Tracking, Assessment and Rating System (STARS) framework of the Association for the Advancement of Sustainability in Higher Education (AASHE) of the US as a starting point, a survey questionnaire shall be administered to all higher education institutions all over Taiwan.

\subsection{Research purpose}

It is obvious that the tool for guidance in environment protection is to adhere to sustainability policies. Recently, many scholars and researchers have invested much effort in developing quantitative indicators for sustainability development. Within this context, protocols were considered from various international studies, such as the Green Flag School Program (GFS, 2012) and the Sustainability Tracking, Assessment and Rating System (STARS) of the Association for the Advancement of Sustainability in Higher Education (Matson, Dautremont-Smith, Newport, \& Walton, 2008) of the US.

Adaptation of these studies was used as basic indicators of the proposed factors relating to Taiwan higher education institutions. Thus, for the purpose of environment protection and sustainability development in higher educational school in this paper, the researcher shall seek to fill the gap of extant literature with the in-depth investigation of the potential impact on some green practice and environmental performance of universities. Hence, we adopted experts argued to further understand and verified the impact or gap about the green practice and environmental performance in current Taiwan's higher education institutions. We also expected to gather some significant information or data through the evaluation system to get the results which can be provided to the higher educational school or government. Further, the results can be expected improve much more the advantage and competitive in the school.

\subsection{Definition and measurement}

\section{Sustainability Development}

Sustainability Development conditions are very different in the different parts of any country, and the quality of life as well as the impacts produced on the environment. The Brundtland Commission Report (United Nation) 
that, "Sustainable development is development that meets the needs of the present without compromising the ability of future generations to meet their own needs" (BCR, 1987). According to Association for the Advancement of Sustainability in Higher Education (AASHE) further defines sustainability in an inclusive way, encompassing human and ecological health, social responsibility, secure livelihoods, and a better world for all generations (Matson et al., 2008).

Some researchers argued that the tool for guidance in environment protection and sustainability development is a strategy. Thus, Ronchi, Federico, and Musmeci (2002) believed that public institutions cannot develop a strategy for sustainable development without a quantitative knowledge of the state of the system. Therefore, it is widely been identified that the environment and sustainable development indicators can be used to improve multiple-objective environmental decision making under conditions of unknown variability (Levy, Hipel, \& Kilgour, 2000).

\section{Green Building}

A green building is said to be an environmentally sustainable building, designed, constructed and operated to minimize the total environmental impacts (Build Green, 2011). Building has involved environmental features in the design and construction of new buildings, major renovations, and interior improvements. It needs to take steps to improve the sustainability performance of their buildings. Buildings are generally the largest user of energy and the largest source of greenhouse gas emissions on sites. Buildings also use significant amounts of potable water. Institutions can design, build, and maintain buildings in ways that provide a safe and healthy indoor environment for people while simultaneously mitigating the building's impact on the outdoor environment. In essence green building should be able to reduced energy consumption, possess a water conservation strategy, and be able to recycle its waste (Build Green, 2011). Hence, the good designed green buildings will save money and create healthier environments.

\section{AASHE}

AASHE is an association of colleges and universities in the U.S. and Canada which working to create a sustainable future. It was founded in 2006 with a mission to promote sustainability in all sectors of higher education from governance and operations to curriculum and outreach through education, communication, research, and professional development (Matson et al., 2008).

\section{STARS}

AASHE's STARS is a voluntary, self-reporting framework for recognizing and gauging relative progress toward sustainability by colleges and universities (Krzmarzick, 2008). It is designed to:

$>\quad$ Provide a guide for advancing sustainability in all sectors of higher education, from education and research to operations and administration.

$>\quad$ Enable meaningful comparisons over time and across institutions by establishing a common standard of measurement for sustainability in higher education.

$>$ Create incentives for continual improvement toward sustainability.

$>$ Facilitate collaboration and information sharing about higher education sustainability practices and performance.

$>\quad$ Recognize sustainability achievements for all institutions, including leaders and beginners.

$>\quad$ Build a stronger, more diverse campus sustainability community.

In addition, schools may be able to receive marketing benefits from using STARS, and prospective students will be able to use STARS ratings in deciding which school to attend. AASHE hopes that all of this evaluation will 
Wang, W. S.

help accelerate and enhance higher education's move toward sustainability (Matson et al., 2008).

\section{Environment Management System}

An Environment Management System (EMS) is a part of an organization's overall management system. It includes the organization structure, planning activities, responsibilities, practices, processes, and resources for implementing and maintaining the EMS (MacDonald, 2005). The practice of Environmental Management Systems is a privileged and integrated way to undertake environmental problems within an organization that can be a valuable way to improve university's environmental performance and promote school sustainability learning.

\section{Literature review}

Facing the extensive change, Wu and Pagell (2011) argued that in response to these green issues, firms have been enforced to reconsider their business models. Besides, due to the fact that the schools are attributed to the part of the organization, schools must synchronize the importance of environmental protection and greening concept. Based on this concept, with the world's growing demand on environmental protection and greening concepts, the school must also comply with the global consistency of the norms and practices, This argued regularly focus on $3 \mathrm{R}$ (reuse, recycling, recovery) are recognized to be an environment sustainability. In environmental sustainability, to reach the goal for people, we need to mitigate waste, emission, and reduce the impact. The first step is to establish the indicators to evaluate the metrics in parts of environment. It is a tool for guidance in environment protection and going through to the sustainability policies, including monitoring of measures, their results, and communication to the public at large (Spangenberg, Pfahl, \& Deller, 2002).

Some recent publication of the Association of University Leaders for a Sustainable Future clearly had indicated that there are many ways in universities which can be involved in greening sustainability, e.g. management, planning, development, education, research, operations, community service, purchasing, transportation, design, new construction, renovation and retrofit (Fleming, 1999). Besides, it is an urgent task to work out policies to respond to the trend of the environmental protection (Petts, 1998). Therefore, this study expected to provide the results about energy saving, environment protection, and sustainability development, that government agencies and schools could be the guidance or counseling about the greening practice and environment performance which conducted in education program.

\subsection{Environment Policy}

The Brundtland Commission was formed by the United Nations in 1983 and the Brundtland Commission Report, issued in 1987, called for greater international cooperation to improve global environmental, economic, and social sustainability. The report focused on that environmental problems were closely tied to problems of economic and social inequality. It offered up an often-quoted definition of the term "sustainable development," stating that, "sustainable development is development that meets the needs of the present without compromising the ability of future generations to meet their own needs" (BCR, 1987).

In Taiwan, The school's environmental policy were governed and audited by the department of environmental organizations and leadership commitment in government. In fact, the Government has also developed a lot of propaganda about the environmental of the controlling requirements. In order to strengthen schools' environmental education, the environment protection association (EPA) and the Ministry of Education will be summit the award, to encourage school engage in environmental education. Furthermore, some plans and strategies are in accordance with the Three-year implementation plan to promote environmental education in schools (Kuo, 2009). 


\subsection{Sustainable development}

The term "sustainable development" was created by the International Union for the Conservation of Nature (IUCN) in 1980 World Conservation Strategy report (IUCN, 1980). After rapidly changing in technology, more and more people aimed to the issue of environment protection because of the tremendous climate change year by year in earth, it stated that "for development to be sustainable it must take account of social and ecological factors, as well as economic ones" (WCED, 1972). It also defined sustainable development as development which "meets the needs of the present generation without compromising the ability of future generations to meet their own needs".

In addition, some researchers argued that one in cited documents as well as in many others (Bell \& Morse, 1999), they recognized the meaning of sustainable development and sustainability is not identical, even though the fundamental sense is basically in the same. The gap or the differences among the researchers were still difficulty to join or definite it. While sustainability indicates a system property referred to as quality, they believed that the key to the sustainable development concept should be provided by the certain quoted Brundtland definition and Article 1 of the Rio Declaration "Human beings are at the centre of concerns for sustainable development" (UNCED, 1992).

However, these articles issued that humans must recognize the world's nature resources is decreasing, on the contrary, the increasing population has caused the nature resources decreasing rapidly, that we are no more choice to live with limited capacities to support life. Today, we can find some other sustainability in Europe. For example, the European Union's Gothenburg Sustainable Development Strategy approved in 2001 and the renewed version endorsed again in 2006, they had placed four out of its six main objectives more or less within the environmental region: it's about the climate change and cleans energy, sustainable transport, sustainable consumption and production, conservation and management of natural resources, and public health. Those are belonging to the field of sustainability development.

\subsection{Social sustainability}

Actually, the diversity of three aspects economic, social and cultural in Taiwan to make development of a unique definition about social sustainability could be very difficult. Some approaches argued that the social dimension of sustainable development is as diverse as the approaches likely to the economic aspect. Thus, in Taiwan, researchers neglected the social sustainability rather than school sustainability. They neglected schools are the ring of organization, nevertheless, some researchers have aimed to the point because of the schools are part of the social too. However, we do know these definitions and others are somehow to be the statements of the general goals of social policy rather than serious attempts to define the social dimension of sustainable development, as argued by Colantonio (2007).

Today, it is so-called the social "pillar" of sustainable development, we know that the goal is to build up the amenity environment for peoples, it depends on the most important and critical in the long-term survival of human civilizations. This is also as shown in Jared Diamond's insightful study of past (and contemporary) societies (Diamond, 2005). Regardless of this recognition, it is not yet fully clear what the critical elements of social un-sustainability are (Moldan, Janoušková, \& Hák, 2012).

Thus, theses study not mentioned this gap, it is expected some researchers to explore the finding in the future. This study focuses on the issues of school sustainability; it is believed that reaching sustainability can also lead to certain reputational benefits in school. First, sustainable schools should have a greater ability to attract and retain high-quality students. The second, they may also get benefits in terms of study, as students are becoming increasingly sensitive to sustainability issues. Last one is an enhanced reputation and school achievement can positively affect relationships with current and potential students, as well as attract to other school students and increasing the school competitive. 


\subsection{Environmental sustainability}

This study aimed to another issue about environmental management, basically it including environment protection, education and research, it may cause environment to be the sustainability. As the world conservation strategy quoted the definition of environment sustainability, it was widely spread and concerned in USA to discuss the environment and the impacts of anthropogenic activities on ecosystem services and functions. Taiwan, nowadays have studied the term of environment sustainability and contributed to implement in society more efforts. It is because of the certain issue has highlighted the need for high-quality, long-term datasets for detecting and understanding environmental change (Parr, Sier, Battarbee, Mackay, \& Burgess, 2003).

Moldan (2009) enlarged the basic principles of environmental sustainability are a long-term perspective and understanding of the non-linear evolution of complex systems, a taking feedbacks into account and regard for different scales, a flexibility and key importance of local conditions. However, the school environment survey is a survey that reached at how healthy in school environment is. It can perceive the environment includes not only the nature but also everything that exiting in our surroundings including the air, water, plants, things inside our buildings, and even the building materials has been included. It is no doubt that the whole buildings have their own environments, including schools. In Taiwan, though most people don't know the fact that school environments can be polluted. This is a little bit severe problem in environmental sustainability to reach the goal.

\subsection{Green Building}

Green building is related to the consumption of energy and resources in the earth, to conduct the least waste, ecology, energy, health characteristics, and building waste reduction. This study expected to find that Green Building must be based on our life, our health, our amenity in the initiate of a perception and normal environmental design for our living surrounding; it is an emphasis on environmental design concept of symbiotic with the Earth's environment, but also a pursuit of sustainable development architectural design (Green Building Association, USA).

Wu and Pagell (2011) identified that the buildings surrounded by or at the perimeter of the green area have better thermal distribution than other buildings away from dense green area. Based on this argued, it may say that it can be conducted if a building near or surrounded by greenery has lower surrounding temperature than the one away from the greenery. Further, the margin effect should be the cost reducing in energy, and toward a sustainability development. Pointed on the green effect, this study seeks to recognize schools that are taking steps to improve the sustainability performance in their buildings.

Additionally, buildings are generally the largest people of energy and the largest source of greenhouse gas emissions on campuses, the buildings are also use a lot amounts of water. Thus, schools have the responsibility to design, build, and maintain the whole buildings in methods that can provide not only a safe but also a healthy amenity environment for students, faculty and staffs. Moreover, it can be simultaneously eliminating the building's impact on the outdoor environment. Thus, school should have collaborated environmental features into the concept or design and construction in new buildings, major renovations, and interior construction improvements. However, this is a significant perspective of new buildings which receive certification in identification of the additional expense and time.

\subsection{Education and Research}

Biggs (1999) suggests that university lecturers has faced a difficult task in adapting to the changing nature of university. It is believed that the major works in school are education and research, for the goal of sustainability in school, the members of school must have an insight toward the achievement. In other side of sustainability, it is believed that the government should ensure schools to be combined with improvements in environmental protection and sustainable development, thus, the school must further strengthen the environmental education and greening actions toward the sustainability of development. 
It is obviously that initiate in secondary education from primary education to implement, it should be continue to implement environmental protection and sustainable development, to do the practice more on this subject should be duty-bound to promote and execution. Hence, the school departments and faculties need to consider the complexity of the teacher education context, consider the curriculum in perceive of the poor quality input, and design some materials that will allow staff members to meet their teaching, research and administrative duty.

Furthermore, some researchers recognize that schools should provide their students with sustainability learning experiences outside the formal curriculum. They suggested building up a sponsor or coordinating sustainability competitions is critical, it can help promote student knowing about sustainability. In addition, the formal education programs and courses that relating sustainability by training and educating future leaders, scholars, workers, and professionals should be implement.

\subsection{Operation}

Matson (2008) stated that the knowing in enhancing cost-effective and operational environmental policies in the sustainable development, STARS identifies five inter-linked objectives for:

$>$ maintaining the integrity of ecosystems through the efficient management of natural resources

$>$ de-coupling environmental pressures from economic growth

$>\quad$ improving information for decision-making: measuring progress through indicators

$>\quad$ the social and environmental interface: enhancing quality of life

$>$ global environmental interdependence: improving governance and co-operation.

According this state that school should get staffing resources to coordinating sustainability efforts. It is believed that a sustainability staff or team which work in school may help school to join its sustainability efforts and toward its sustainability goals properly. Similarly, the designating staff or team resources for sustainability cooperation represent school's commitment to sustainability. Likewise, if a school president or vice president granting the staff or team to perform academic and operational purview, that means supporting the staff report directly to them, it indicates that the staff or team has a lots of impacts within the school and the school reach the priority sustainability.

Besides, Matson et al. (2008) argued that school should have a sustainability recognition program. This recognition program relative award and commitment programs, and it could help announce sustainability achievements and reward the people in essential. Certainly, the awards and commitments programs simultaneous create an incentive for further improvement. It is believed that if school can collaborates with others to help them building campus sustainability extensively, schools can provide more significant contributions to sustainability by sharing their experiences and expertise in operation with other colleges and universities. Thus, sharing best practices and lessons by each other can help other schools recognized the facts that enhance the whole higher educational school toward the sustainability.

\subsection{Energy and Climate}

Global climate change has imposed a set of impacts for which some of the existing infrastructure, including the energy infrastructure, it may not have been projected to withstand (Schaeffer et al., 2012). This is not occurred in certain country or certain organization, besides, it could not only affect energy supply, but also increase future costs. For example, Larsen et al. (2008) estimated the replacement costs of Alaska's public infrastructure (including some energy infrastructure) with and without the effects of climate change. They found that climate change could add $\$ 3.6$ to $\$ 6.1$ billion to future cost of infrastructure up to 2030 and reach additional 
Wang, W. S.

$\$ 5.6$ to $\$ 7.6$ billion up to 2080 (Schaeffer et al., 2012).

In Taiwan, mostly schools still use potable water for irrigation. Irrigation is often the largest user of potable water on campuses. Based on this status, schools should find substitute water recycled to use water and captured rainwater to supply their irrigation needs. Further, it needs to take account into of the cost in delivering and treating water; it requires a lot of energy. In addition, as the global warming will be increase the limitation on water supplies, the groundwater supplies should be consumed faster than they are being collected in the places. Investing in water conservation and water re-use is also a prudent risk management strategy. Schools should take into account the water using issue for sustainability development.

More and more studies on climate change relatives on energy are being published and some authors have provided informative viewpoints of unique segments within the energy issues. Regarding the impacts of climate change on energy demand at the global level; Wilbanks et al. (2008) stated that global climate change may affect electricity production by affecting the generation cycle efficiency and cooling water requirements of thermal power plants. However, regardless being one of the important systems for social - economic and schools development. In Taiwan, this study is expected to understand the energy systems and the effects of future changing about climate factors whether or not involve in their planning and operation especially in school. Furthermore, school should aim to energy consumption issue making the proactive environment planning and management.

\subsection{Environmental Planning and Management}

Global warming is treating lots of impacts throughout the world, like tremendous weather change. For example, the sea level rising and land space declining, species moving and extinction, water shortages and declining agricultural production. Thus, schools should set sustainability concept into their primary campus plans and keep those plans which have developed moving towards sustainability. It is believed that Sustainability plans and Climate plans will provide a clear understanding for achieving sustainability goals.

Porter and Van Der Linde (1995) also stated that pollution is the concrete representation of the inefficient uses in resources. Hence, schools should have the preventive pollution cognition at a high benchmark in their major plans in environment protection. Environment protection is based on a comprehensive plan to move towards sustainability. Thus, how to embed sustainability into the campus with major plan, it may help school understanding the sustainability objectives when leader or staff making decisions about its facilities, the school obviously can reduce its global warming impact.

Lacking of suitable environmental planning and management in the past years has cost Asian economies billions of dollars in lost environmental resources and amenities (Jalal \& Rogers, 2002). It is believed that the increasing of GDP growth rates has been usually followed by positive environmental changes. For example, the improvement of environmental quality or reduction of environmental impacts, or a positive sustainable event, it is useful to evaluate the environment management for achieving the sustainability goal.

\section{Methodology}

\subsection{Research Paradigm}

This study employed the descriptive research paradigm; a qualitative research that is concerned with how something that exists is related to some preceding event that has influenced or affected a present condition or event. Descriptive research, according to Best (1970) is concerned with conditions or relationships that exist, practices that prevail, beliefs, points of views, or attributes that are held, processes that are ongoing, effects that are being felt; or trends that are being develop.

A quantitative survey was also used in gathering the current implementation of green sustainability schools 
An initial study on managing sustainability schools in Taiwan

in Taiwan. Surveys are used to gather information at a particular point in time with the intention of describing the nature of existing conditions, or identifying standards against which existing conditions can be compared, or determining the relationships that exist between specific events (Cohen, Manion, \& Morrison, 2007). Most survey will combine nominal data on participants' backgrounds and relevant personal details with other scales (Weisberg, Kronsnick, \& Bowen, 1996). Surveys are often administered to a large number of respondents, hence, survey research are often coined to as quantitative research, which has a high level of structure and low level of researcher involvement with the study population (Axinn \& Pearce, 2006).

A researcher revised survey questionnaire based on the above mentioned literature review was send to 164 schools all over Taiwan. Survey is addressed to the institution's green (sustainability) office. In any case the institution does not have such an office; the survey is then addressed to the property department office or to the office of general affairs.

\subsection{Research framework}

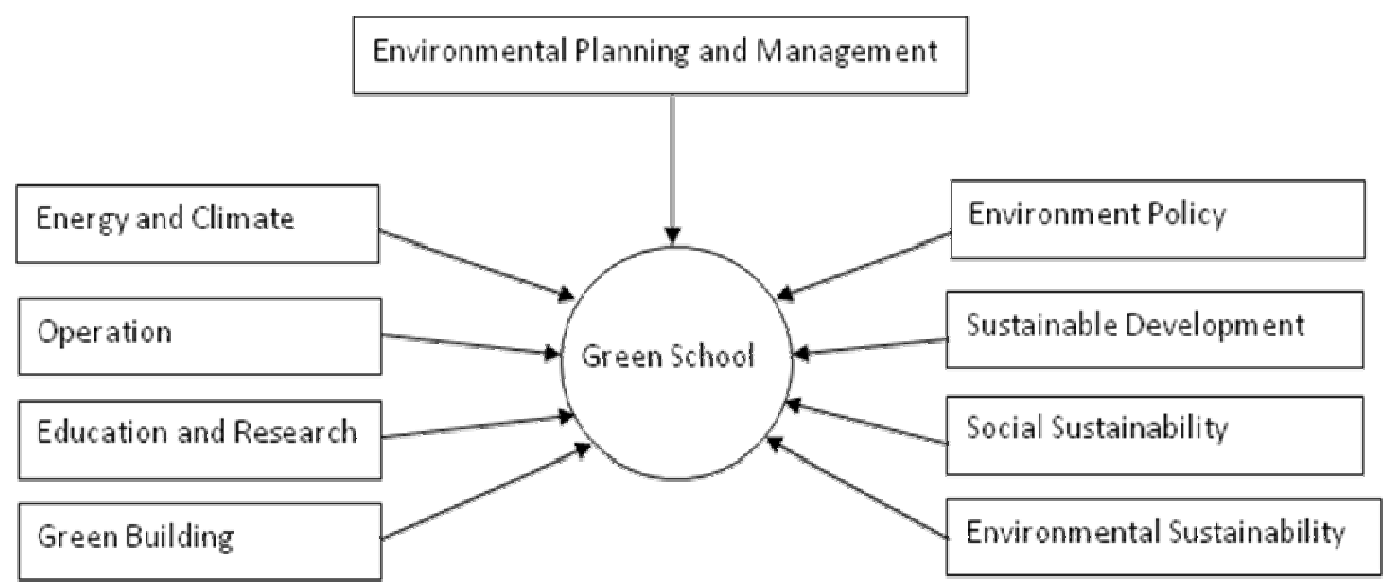

Figure 1. Research Framework

\subsection{Research participants}

For the current study, a survey questionnaire was send to all the higher education institutions in Taiwan $(\mathrm{N}=164)$. A total of 38 valid questionnaires were collected with a return rate of $23.2 \%$. Table 1 shows the respondents' profile, while table 2 shows the responding schools' profile.

Table 1

Respondents' profile $(N=38)$

\begin{tabular}{|c|c|c|}
\hline Items & $n$ & $\%$ \\
\hline \multicolumn{3}{|l|}{ Gender } \\
\hline Male & 33 & 86.8 \\
\hline Female & 5 & 13.2 \\
\hline \multicolumn{3}{|l|}{ Ownership } \\
\hline National (government/public) & 27 & 71.1 \\
\hline Private & 11 & 28.9 \\
\hline \multicolumn{3}{|l|}{ Institution type } \\
\hline Typical university & 20 & 52.6 \\
\hline Technical/vocational university & 13 & 34.2 \\
\hline Junior college & 5 & 13.2 \\
\hline \multicolumn{3}{|l|}{ Location } \\
\hline Urban & 20 & 52.6 \\
\hline Suburban & 13 & 34.2 \\
\hline Rural & 5 & 13.2 \\
\hline
\end{tabular}


Wang, W. S.

Table 2

Respondents' profile by classification $(N=38)$

\begin{tabular}{lccc}
\hline \multicolumn{1}{c}{ Items } & Urban & Suburban & Rural \\
\hline National (government/public) & & & \\
Typical university & 6 & 9 & 2 \\
Technical/vocational university & 5 & 0 & 3 \\
$\quad$ Junior college & 2 & 0 & 0 \\
Private & 3 & 0 & 0 \\
Typical university & 1 & 4 & 0 \\
Technical/vocational university & 3 & 0 & 0 \\
Junior college & & & \\
\hline
\end{tabular}

\section{Results and discussions}

After the survey is collected and tabulated. Data analysis includes descriptive statistics, T-test, and analysis of variance (ANOVA), using the Statistics Package for Social Scientist (SPSS) version 15. For the percentage of land use, results show that majority of school properties are devoted for use in landscaping, gardening, and/or open fields with a mean of 3.89 , while the least land usage is attributed to laboratory use with a mean of 1.58 . These results imply that even though most respondent schools are in the urban areas (20 or 52.6\%), institutions still tries to maintained a healthy balanced land used policy (Please see Table 3).

\section{Table 3}

Schools' percentage of land use

\begin{tabular}{lll}
\hline \multicolumn{1}{c}{ Items } & Mean & SD \\
\hline Land use for landscaping, garden, or open fields & 3.89 & 1.290 \\
Undeveloped land & 3.18 & 1.291 \\
Road with pavement & 1.71 & 0.984 \\
School campus building & 2.21 & 0.905 \\
Laboratory & 1.58 & 0.722 \\
\hline Note. &
\end{tabular}

Note. Mean equal to: $1=$ Less than $10 \%, 2=10$ to $30 \%, 3=30$ to $50 \%, 4=50$ to $70 \%$, and $5=$ above $70 \%$

Results also show that of the 38 respondents the overall average sustainability is 29.61 out of a 49 item inventory. This signifies that Taiwan higher education institutions are moderately sustainable with the factor operations having the highest mean score of 4.66 out of a 7 item scale. In addition, in order to determine if there are any difference with the public and privately owned institutions. An independent-samples t-test was conducted to compare the sustainability operation of public and private higher education institutions in Taiwan. Results show that public schools $(\mathrm{M}=5.26, \mathrm{SD}=1.5)$ performed significantly higher than private ones $(\mathrm{M}=3.18, \mathrm{SD}=$ $1.4) ; \mathrm{t}(38)=3.976, p=0.000$. These results suggest that the type of schools do varies with their day to day operations regarding sustainability strategies (Please see Table 4).

\section{Table 4}

Overall scores of sustainability factors

\begin{tabular}{lll}
\hline \multicolumn{1}{c}{ Items } & Mean & SD \\
\hline Environmental sustainability & 1.92 & 1.100 \\
Social sustainability & 2.11 & 1.290 \\
Green building & 2.39 & 0.638 \\
Sustainable development & 2.63 & 1.344 \\
Education and research & 3.24 & 1.937 \\
Environmental policy & 3.66 & 2.539 \\
Energy and climate & 4.42 & 1.328 \\
Environmental planning and management & 4.58 & 0.826 \\
Operations & $\mathbf{4 . 6 6}$ & 1.729 \\
\hline
\end{tabular}


An initial study on managing sustainability schools in Taiwan

Table 5

Sustainability factors and school type

\begin{tabular}{lccc}
\hline Items & $\begin{array}{c}\text { Typical } \\
(n=20)\end{array}$ & $\begin{array}{c}\text { Science/ } \\
\text { Technology }(n=13)\end{array}$ & $\begin{array}{c}\text { Junior College } \\
(n=5)\end{array}$ \\
\hline Environmental sustainability & 2.20 & 2.00 & 0.60 \\
Social sustainability & 2.05 & 2.08 & 2.40 \\
Green building & 2.40 & 2.54 & 2.00 \\
Sustainable development & 2.80 & 2.69 & 1.80 \\
Education and research & 4.30 & 2.38 & 1.20 \\
Environmental policy & 4.30 & 2.46 & 4.20 \\
Energy and climate & 4.35 & 4.38 & 4.80 \\
Environmental planning \& management & 4.80 & 4.31 & 4.40 \\
Operation & 5.25 & 3.77 & 4.60 \\
OVERALL & 32.45 & 26.62 & 26.00 \\
\hline
\end{tabular}

Note. Items in bold represents significant difference in mean scores.

A one-way between-groups analysis of variance (ANOVA) was conducted to explore the impact of school type (typical, technical and vocational, and junior colleges) on the various sustainability factors. In terms of school type, ANOVA results show that Junior colleges [ $\mathrm{f}(2,35)=5.27, p=0.010]$ shows a significant difference between the typical and technological universities in terms of their Environmental sustainability. Post-hoc comparisons using the Tukey HSD test indicates that Junior colleges shows significant lower mean scores as compared to typical $(M=2.20, S D=1.01)$ and technological $(M=2.00, S D=1.08)$ universities. Such results suggest that since junior colleges are quite small in size and limited in terms of resources; it is understandable that their performance is not as good as compared to the typical and technical universities (Please see Table 5).

Table 6

Sustainability factors and school location

\begin{tabular}{lccc}
\hline \multicolumn{1}{c}{ Items } & Urban $(n=20)$ & Suburban $(n=13)$ & Rural $(n=5)$ \\
\hline Environmental sustainability & 1.45 & 2.54 & 2.20 \\
Social sustainability & 1.80 & 2.77 & 1.60 \\
Green building & 2.00 & 2.77 & 3.00 \\
Sustainable development & 2.50 & 3.23 & 1.60 \\
Education and research & 2.55 & 4.46 & 2.80 \\
Environmental policy & 3.35 & 5.15 & 1.00 \\
Energy and climate & 4.05 & 4.85 & 4.80 \\
Environmental planning \& management & 4.65 & 4.85 & 3.60 \\
Operation & 4.50 & 4.85 & 4.80 \\
OVERALL & 26.85 & 35.46 & 25.40 \\
\hline
\end{tabular}

Note. Items in bold represents significant difference in mean scores.

A one-way between-groups analysis of variance (ANOVA) was conducted to explore the impact of school location (urban, suburban, and rural) on the various sustainability factors. Results show that the there is a statistically significant difference with regards to the overall sustainability of the school in various locations with [f $(2,35)=6.85, p=0.003$ ]. Furthermore, significant differences were also found in various other factors such as Green building with [f $(2,35)=14.26, p=0.000$ ], Environmental planning \& management with [ $f$ $(2,35)=5.24, p=0.010]$, Environmental policy with $[\mathrm{f}(2,35)=6.74, p=0.003]$, and Education and research $[\mathrm{f}$ $(2,35)=4.80, p=0.014]$ (Please see Table 6). 
In addition, post-hoc comparisons using the Tukey HSD test indicates that the overall sustainability mean score of suburban $(\mathrm{M}=35.46, \mathrm{SD}=8.64)$ schools is significant different from the schools located in the urban $(\mathrm{M}=26.85, \mathrm{SD}=5.72)$ and rural $(\mathrm{M}=25.40, \mathrm{SD}=7.67)$ areas. Such results imply that suburban schools have the best opportunity in pursuing sustainability strategies, since the institutions both have the capability to expand and together with ample financial support to accomplish its goals.

Furthermore, urban $(\mathrm{M}=2.00, \mathrm{SD}=0.56)$ school shows significant lower mean scores in the factor Green building as compared to schools located in the suburban $(\mathrm{M}=2.77, \mathrm{SD}=0.44)$ and the rural $(\mathrm{M}=3.00, \mathrm{SD}=$ $0.00)$ areas. While, Rural $(\mathrm{M}=3.60, \mathrm{SD}=0.55)$ school shows significant lower mean scores in the factor Environmental planning \& management as compared to schools located in the urban $(\mathrm{M}=4.65, \mathrm{SD}=0.93)$ and the suburban $(\mathrm{M}=4.85, \mathrm{SD}=0.38)$ areas. Lastly, Suburban $(\mathrm{M}=5.15, \mathrm{SD}=2.51)$ school shows significant higher mean scores in the factor Environmental policy as compared to schools located in the rural $(\mathrm{M}=3.60, \mathrm{SD}$ $=0.55)$ areas. In addition, Suburban $(\mathrm{M}=4.46, \mathrm{SD}=1.61)$ school shows significant higher mean scores in the factor Education and research as compared to schools located in the urban $(\mathrm{M}=2.55, \mathrm{SD}=1.88)$ areas.

\section{Conclusion}

As Taiwan higher education institutions advances towards a sustainable society, schools all over Taiwan have been trying to adapt a green school strategy. However, most institutions are still impeded either by their geographical location or by their school type. Certainly such impediment can be seen as both a challenge and a barrier for attaining the sustainable goals; ultimately Taiwan higher education institutions shall strive even harder to provide a better future for our society.

NOTE: This paper is part of a Master's degree thesis undertaken by the author. In addition, some parts of the paper were also presented in an academic conference held on 2012.

\section{References:}

Axinn, W. G., \& Pearce, L. D. (2006). Mixed method data collection strategies. New York: Cambridge University Press. http://dx.doi.org/10.1017/CBO9780511617898

BCR. (1987). The Brundtland commission report - Our common future: The report of the world commission on environment and development. Washington, DC: United Nation.

Bell, S., \& Morse, S. (1999). Sustainability indicators: Measuring the immeasurable. London, UK: Earthscan Publication.

Best, J. W. (1970). Research in education. Englewood Cliffs, NJ: Prentice Hall.

Biggs, J. (1999). Teaching for quality learning at university. Buckingham: Open University Press.

Build Green. (2011). Definition. Retrieved May 5, 2012, from http://buildgreen.co.nz/definition.html

Cohen, L., Manion, L., \& Morrison, K. (2007). Research methods in education. New York: Routledge.

Colantonio, A. (2007). Measuring social sustainability: Best practice from urban renewal in the EU. Oxford, UK: Oxford Brookes University.

Diamond, J. (2005). Collapse: How societies choose to fail or survive. New York, NY: Viking Penguin/Allen Lane.

Dietz, T., \& Rosa, E. A. (1994). Rethinking the environmental impacts of population, affluence and technology. Retrieved May 5, 2012, from http://www.jayhanson.us/page111.htm

Fleming, R. (1999). Sustainability in architecture courses at the Philadelphia college of textiles and science. Retrieved May 5, 2012, from http://www.ulsf.org/pub_declaration_curvol31.html

GFS. (2012). The green flag program survey. Retrieved May 5, 2012, from http://www.greenflagschools.org/Survey.pdf

IUCN. (1980). World conservation strategy. Retrieved May 5, 2012, from http://data.iucn.org/dbtw-wpd/edocs/WCS-004.pdf

Jalal, K. F., \& Rogers, P. P. (2002). Measuring environmental performance in Asia. Ecological Indicators, 2(1-2), 39-59. http://dx.doi.org/10.1016/S1470-160X(02)00054-7

Krzmarzick, B. (2008). STARS: Sustainability, tracking, assessment, and rating system. Retrieved May 5, 2012, from http://www.plu.edu/sustainability/documents-forms/STARS\%20report.pdf

Kuo, D. (2009). Campuses warm to tackling conservation challenge. Retrieved May 5, 2012, from 
An initial study on managing sustainability schools in Taiwan http://www.chinapost.com.tw/taiwan/local/taoyuan/2009/12/30/238564/Campuses-warm.htm

Larsen, P. H., Goldsmith, S., Smith, O., Wilson, M. L., Strzepek, K., Chinowsky, P., et al. (2008). Estimating future costs for Alaska public infrastructure at risk from climate change. Global Environmental Change, 18(3), 442-457. http://dx.doi.org/10.1016/j.gloenvcha.2008.03.005

Levy, J. K., Hipel, K. W., \& Kilgour, D. M. (2000). Using environmental indicators to quantify the robustness of policy alternatives to uncertainty. Ecological Modelling, 130(1-3), 79-86.

MacDonald, J. P. (2005). Strategic sustainable development using the ISO 14001 Standard. Journal of Cleaner Production, 13(6), 631-643.

Matson, L., Dautremont-Smith, J., Newport, D., \& Walton, J. (2008). Sustainability tracking, assessment and rating system for colleges and universities.

Moldan, B. (2009). The conquered planet [In Czech]. Washington, DC: Island Press.

Moldan, B., Janoušková, S., \& Hák, T. (2012). How to understand and measure environmental sustainability: Indicators and targets. Ecological Indicators, 17, 4-13. http://dx.doi.org/10.1016/j.ecolind.2011.04.033

Parr, T. W., Sier, A. R. J., Battarbee, R. W., Mackay, A., \& Burgess, J. (2003). Detecting environmental change: Science and society? Perspectives on long-term research and monitoring in the 21 st century. Science of The Total Environment, 310(1-2), 1-8. http://dx.doi.org/10.1016/S0048-9697(03)00257-2

Petts, J. (1998). Environmental responsiveness, individuals and organizational learning: SME experience. Journal of Environmental Planning and Management, 41(6), 711-730. http://dx.doi.org/10.1080/09640569811380

Porter, M. E., \& Van Der Linde, C. (1995). Green and competitive: Ending the stalemate. Harvard Business Review 73(5), 120-134.

Portney, K. E., \& Ber, J. M. (2011). Civil society and sustainable cities. Paper presented at the Princeton Conference on Environmental Politics: Research Frontiers in Comparative and International Environmental Politics.

Pujari, D. (2006). Eco-innovation and new product development: Understanding the influences on market performance. Technovation, 26(1), 76-85. http://dx.doi.org/10.1016/j.technovation.2004.07.006

Ronchi, E., Federico, A., \& Musmeci, F. (2002). A system oriented integrated indicator for sustainable development in Italy. Ecological Indicators, 2(1-2), 197-210. http://dx.doi.org/10.1016/S1470-160X(02)00045-6

Schaeffer, R., Szklo, A. S., Pereira de Lucena, A. F., Moreira Cesar Borba, B. S., Pupo Nogueira, L. P., Fleming, F. P., et al. (2012). Energy sector vulnerability to climate change: A review. Energy, 38(1), 1-12. http://dx.doi.org/10.1016/j.energy.2011.11.056

Spangenberg, J. H., Pfahl, S., \& Deller, K. (2002). Towards indicators for institutional sustainability: lessons from an analysis of Agenda 21. Ecological Indicators, 2(1-2), 61-77. http://dx.doi.org/10.1016/S1470-160X(02)00050-X

UNCED. (1992). Rio declaration on environment and development: Report of the United Nations conference on environment and development. Washington, DC: United Nation.

WCED. (1972). United Nation report of the world commission on environment and development. Washington, DC: United Nation.

Weisberg, H. F., Kronsnick, J. A., \& Bowen, B. D. (1996). An introduction to survey research, polling, and data analysis (3rd edition). Thousand Oaks, CA: Sage.

Wilbanks, T. J., Bhatt, V., Bilello, D. E., Bull, S. R., Ekmann, J., Horak, W. C., et al. (2008). Effects of climate change on energy production and use in the United States. Washington, DC: Department of Energy, Office of Biological, Environmental Research.

Wu, Z., \& Pagell, M. (2011). Balancing priorities: Decision-making in sustainable supply chain management. Journal of Operations Management, 29(6), 577-590. http://dx.doi.org/10.1016/j.jom.2010.10.001

Zhang, B. (2011). Optimal policy for a mixed production system with multiple OEM and OBM products. International Journal of Productions Economics, 130(1), 27-32. http://dx.doi.org/10.1016/j.ijpe.2010.10.010 
Wang, W. S. 